\title{
BUREAUCRACY, CASE GEOGRAPHY AND THE GOVERNANCE OF THE INEBRIATE IN
}

SCOTLAND (1898-1918)

\section{Abstract:}

This article considers the late-Victorian and Edwardian legislative treatment of problem drunkenness in Scotland under the 1898 Inebriates Act. It examines the uneven enactment of the law, by geography and gender, and exposes how mundane questions of bureaucracy, of finance and jurisdiction, intersected with the institutional management of people convicted under it. I present an analytical framework of case geography to examine the ways in which bureaucratic and not simply medical interventions came together to shape people's unfolding futures. Their removal to - and oftentimes between - institutions produced and did not simply resolve bureaucratic challenges. In conclusion I call for a greater awareness of the ways in which such mobile lives shaped policy: they tested the geographical imagination of government and with it the viability of this inebriate system.

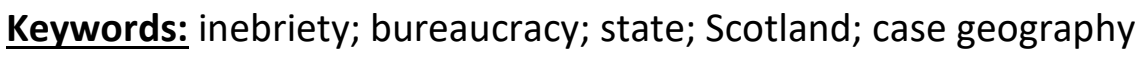




\section{$1 \quad$ INTRODUCTION}

Bureaucratic practices shape the geography of legislative action. They are a policy's implementation, however effective: its everyday political geographies, however hidden (Mountz, 2010). If critical work on statecraft has shown how mundane processes work to give that state a kind of public coherence and a kind of imaginative geography of being everywhere and practically nowhere at the same time (see Mitchell, 2006; Painter, 2006), then it is by studying the governmental back-stage that we can reach a more disaggregated and yet locatable understanding of state power. Akhil Gupta (2012: 47) describes the decision making of administrators as a daily 'friction between agendas, bureaus, levels, and spaces that make up the state' (Gupta 2012: 47). This article is a study of those frictions, and their powerful geographical effects.

My case study is the application in Scotland of the little-known and ultimately shortlived Inebriates Act (1898, 61 \& 62 Vict. c. 60), which created an institutional system for dealing with repeat offenders with convictions for drunkenness. The legislation was permissive, and relied upon a range of authorities and a balancing of discretionary and disciplinary measures characteristic of Victorian liberalism (Beckingham, 2010; Wallis, 2018). It led to the licensing of five certified reformatories - the most notable, called Girgenti, belonging to the city of Glasgow - and a state reformatory within Perth prison. I connect the Girgenti records to local council minutes, published parliamentary papers, Perth materials and private files compiled by civil servants in the Scottish Office, now held in the National 
Records of Scotland. Felix Driver has noted that through a focus on either 'local' or 'national' archives, historical research can reinforce a dualistic reading of the state (Driver, 1993: 16). The dispersed nature of these records not only reflects the uneven geography of engagement with the legislation. I argue that this very geography was created and tested by attempts to implement the Act, to settle responsibilities across these different governmental authorities.

Looking to debates in legal geography, section two identifies the bureaucratic battles that were fought to settle responsibility on authorities working at different jurisdictions and scales (see Blomley, 2014). While the Act was ostensibly gender blind attitudes to alcohol were not: only nine of the 307 admitted to certified reformatories between 1901 and 1913 were men (BPP, 1914 [Cd. 7440] XXXVI.297: 3). I make a distinctive contribution to the historiography of the Act (Hands, 2003; Hunt et al., 1989; McLaughlin, 1991; Morrison, 2008; Soares, 2015; Valverde, 1998; Wallis, 2018; Zedner, 1991), by highlighting the part intra-state frictions played in limiting its implementation. Details of individual cases and management issues were gathered into files and routed by civil servants up to figures including the government inspector under the Act (Dr James Crauford Dunlop), its legal advisor (Lord Advocate), and the government minister (Secretary for Scotland) (see Milne, 1957 for a history of the Scottish Office). This routing and circulation of files is an importantly material metaphor for how decisions were made (see Dittmer, 2016). For Patrick Joyce (2013: 167), the file 'actions the world, the paper form of doing things, which if not the actual form in which these things get done, is the form without which nothing could 
have got done at all'. I use these files and other parliamentary reports to analyse how things 'got done', how women were selected and treated.

Archived sources never were simply spaces of record; they were spaces of action, shaping unstable and unfolding futures, a dyad of 'imperative and information' (Vissman, 2008: 8). Section three advances a distinctive analytical approach of case geography to theorise the circulation of the lives that became entangled in this system. On the face of it the reformatory stands as an archetypal space for disciplining those deemed unable to live with the freedoms of self-regulating liberal subjects (see Disney, 2017; Salter, 2017). In the course of their reformatory sentences several inmates were identified as 'unmanageable', often due to perceived mental defectiveness, and were moved to other institutions. Circulation also reflects, therefore, 'the impossibility to discipline' (Kotef, 2015: 5). Such transfers were less as an attempt to discipline mobility than to discipline through it (Moran et al., 2011: 449; also see Philo, 2014: 495). Here I subtly shift from case histories - the pasts that brought people to reformatories - to case geographies, to the work of mobility in the unfolding management of individuals when multiple futures were possible. Drawing on the work of Tania Murray Li (2007: 277) I therefore examine not only the 'practices' and 'effects' of power, how the policy took hold, but show how this movement across authorities and their archives tested earlier bureaucratic settlements. Section four considers the entanglement of these mobile lives with unfolding bureaucratic battles that shaped the Act's undoing, and shifted the 'programming' of the problem to be regulated (Li 2007: 277). 
Responding to work on mobility in carceral geography, I argue that sighting circuits of 'people, objects and practices' can open up a site like the reformatory, placing it in a wider bureaucratic as well as institutional system of 'risk containment' (Gill et al., 2018: 197). Understanding how offers a response to Peters and Turner's (2017: 2) challenge to consider movement when analysing spaces 'of relative stasis'. In addition, if the analogy of the circuit appears rather 'flat' (Gill et al., 2018: 197) my moving examples reveal contingent and volatile efforts to determine the geographical horizons and responsibilities of government across putatively different hierarchical scales. Their movement raises interpretive challenges around agency and resistance (Moore, 2018), for files record ways in which the subjects of disciplinary power challenged contemporary legal and medical categorisations (see Hands, 2013). Whilst I refer to individuals by their institutional admission numbers, this is not seek to deny such agency but rather at once respect privacy and emphasise the force of categorisation (see Moore, 2010). Given the complexities around historic terminology and diagnosis, I do not adjudicate on records of behaviours as evidence of mental ill-health or, reading against the grain, conscious resistance to reformatory discipline (see Parr, Philo and Burns, 2003; Wolch and Philo, 2000). Instead I suggest these can be approached at a broader scale, because by tracing these complex and disruptive lives across authorities and institutions it becomes possible to show how together they exercised a cumulative restraint on attempts to delimit inebriety.

\section{$\underline{2}$ FRAMING INEBRIETY}


This section focuses on the decision matrices that shaped the local operation of the legislation and restricted its field of vision to a distinctive group of working-class problem women. The 1898 legislation supplemented the Habitual Drunkards Act of 1879, which had led to the licensing of a series of private retreats for wealthy problem patients. Under that earlier Act only by self-certifying before a justice of the peace could individuals be admitted for treatment. Critics complained this mistakenly protected freedom of choice at the very time when people's capacity for right-judgment was wanting (Valverde, 1998). Medics, keen to recode alcoholism as a disease rather than a vice, had championed institutional treatment to stop problem drinkers drifting 'like tangle in the tide' (Sutherland, 1899: 718). Their ambitions were never realised, for the new legislation decisively framed inebriety as a problem for criminal justice, correcting that anomaly of freedom with the force of criminal prosecution and reformatory sentences of up to three years (Beckingham, 2010).

The use of convictions helped head off libertarian opposition to lengthy sentencing, for they demonstrated an inability to with liberal freedom. However, the 1898 Act's reliance on criminal justice created what Hands (2013: 63) terms a 'two-tier system' of private retreat 'care for the wealthy' and reformatory 'imprisonment for the poor'. The Act included clauses for use in the magistrate courts of England and Wales and separate ones to account for Scotland's judicial system. These clauses both targeted two types of criminals. North of the border, section 23 targeted those convicted on indictment for offences punishable with imprisonment or penal servitude, provided drink was a proven contributing factor. This included cases of child cruelty, for example. Unless an individual admitted to being a habitual drunkard a jury would have to rule on that point as well as on the main charge, 
such as child neglect, which risked introducing a very 'arbitrary' standard of assessment (BPP, 1909 [Cd. 4767] XXVI.601: 121, question 3295). The vast majority of those convicted on section 23 charges were sent to Perth, with only four cases being sent to local certified reformatories (BPP, 1909 [Cd. 4767] XXVI.601: 12, question 225). Section 24 dealt with people who were guilty of four drunkenness-related offences in a twelve-month period, but only if the offence was detected by a constable, a court was willing to convict and a local authority committed to pay towards the costs of providing accommodation.

Although the published legislation said nothing of class or gender, the gaze of inebriate criminal justice would fall on women of the city street, women with lengthy histories and complex geographies of incarceration for the likes of petty theft, breaches of the peace, and prostitution. Thora Hands (2013: 63) describes reformatories as containing 'the shifting boundaries of deviant femininity' and an all too public set of behaviours. Even when taking account of its mix of section 23 and 24 admissions, women outnumbered men in Perth by a factor of four to one (129 to 33 by the end of 1913) (BPP, 1914 [Cd. 7403) XLV.783: 84). The government inspector Dr James Dunlop concluded that they were 'not a true sample. They are selected either by personal or society influence' (BPP, 1909 [Cd. 4767] XXVI.601: 12, question 231). Women's drinking was a gathering point for broader social concerns about liberal freedoms, motherhood and even racial degeneration (Wallis 2018). It may be hard to escape Mariana Valverde's (1993: 88) conclusion that the 1879 and 1898 Acts proved a useful 'temporary strategy' for dealing with those broader issues, nevertheless it is important to understand that this wasn't always the intention. In the 
remainder of this section I examine the unfolding bureaucratic battles that helped define its use, beginning with conflicting interpretations of its very wording.

Indictable offences in Scotland were heard in Sheriff Courts. Yet a whole series of drink-related offences were historically dealt with under Scottish common law in lower police courts, creating a perception that these could not qualify under the Act because they would not be heard before a Sheriff (BPP, 1908 [Cd. 4219] XXXVIII.1, pp. 13-14; BPP, 1909 [Cd. 4767] XXVI.601: 157, question 4187). This was challenged in a section 23 case in Kirkwall, Orkney, when the Sheriff convicted a man who had been charged on indictment for the common law offence of breaching the peace while under the influence of alcohol. Offering his expert opinion to the Scottish Office, the Lord Advocate concluded that: 'any common law offence however petty which involves imprisonment may be prosecuted by indictment'. The man became the first person to be admitted to Perth (Figure 1). Prison commissioner McHardy and civil servants worried that other local authorities might now try and ship petty offenders to Perth at the expense of central government (NRS, $\mathrm{HH} / 57 / 63$, 1627/190 file dated 25 September 1901 and 1627/196, file dated 20 September 1901). The Scottish Office responded by explaining that Perth was for section 23 cases that involved offences so severe that they would normally be reported to the Crown Office for opinion. This was calculated to block the movement of petty offenders, but it was actually interpreted as preventing prosecutions in serious child cruelty cases - unintentionally limiting the law's application (BPP, 1909 [Cd. 4767] XXVI.601: 11, question 201). 


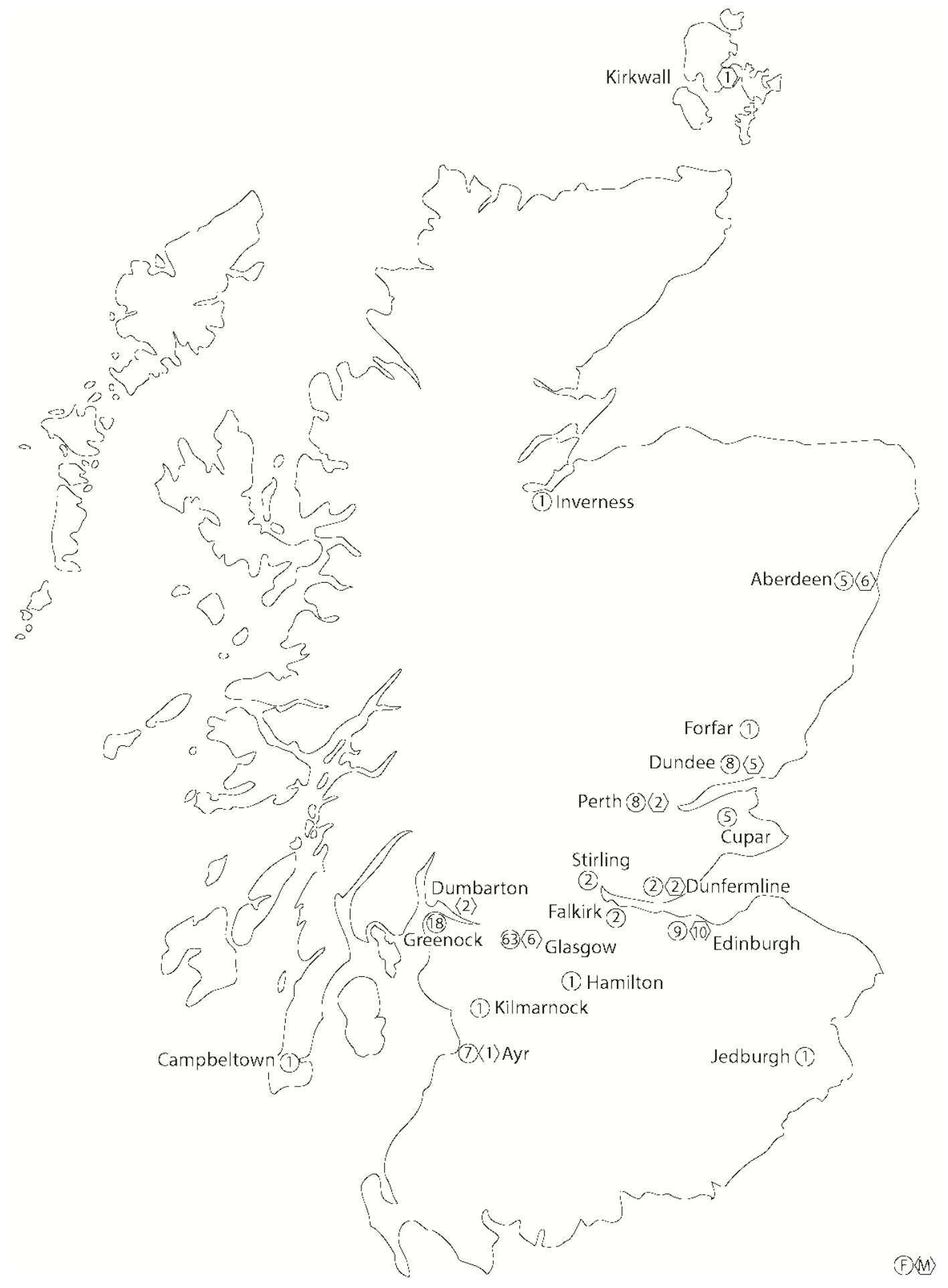

Figure 1, Map showing committing courts in case of admissions (direct and transferred) to Perth State Inebriate Reformatory, 26 September 1901 to 31 December 1914. Shetland (no cases) omitted. (BPP, Reports of the Inspector for Scotland under the Inebriates Acts and Annual Reports of the Prison Commissioners). 
Stirling's County Clerk told the Scottish Office in 1899 that in the preceding three years they had had no incidents where charges valid under section 24 had come before a Sheriff (NRS, HH/57/62, 1627/71, file dated 11 March 1899). The County and Town Councils of Perth, Forfar and Fife agreed that even if they could identify people who would benefit from treatment it would be 'useless' for them to open a reformatory (PKA, PE1/1/24, Town Council Minutes, 1898-1900: 187, 6 November 1899). Doubtless concerned about the financial outlay of such a reformatory, councils could use the law's framing to justify inaction - keeping people away from the legislation. Dundee's Chief Constable Dewar told his town's magistrates in April 1902 that locally there were 91 men and 129 women who could qualify as habitual drunkards under the Act. Only 26 were eligible for a certified reformatory, he said, which Dundee did not have. Perhaps thinking of the Kirkwall case, he explained that common law offences committed while under the influence of alcohol could be remitted to the Sheriff and possibly sent to Perth (DCA, Town Council Minutes, 1901-2: 660, 23 April 1902). Such a reading, if widely applied, threatened to overload the state reformatory. More importantly it held out a way for local authorities to de-place problem people from within their jurisdictions, without significant financial commitment.

Dundee demanded the scope of the law be broadened before it would subscribe to a facility, but Under-Secretary Colin Scott-Moncrieff penned an acerbic letter to remind its magistrates of their immediate duty to apply the existing law. Broadening it would achieve nothing if there was no 'accommodation provided for even 26' (DCA, Town Council Minutes, 1901-2: 1002, 23 July 1902). Police Chief Dewar protested that the town's magistrates could 
not act in isolation: 'Without the sympathy and hearty co-operation of the Sheriff, there is no use in erecting a Certified Reformatory'. Internal Scottish Office notes concluded that Dewar did not understand the law, but they were powerless to force the issue (NRS, HH57/64 1627/292, file dated 29 July 1902; DCA, Town Council Minutes, 1901-2: 1274, 24 September 1902). Dundee did in fact approach other councils north of the Forth to investigate a jointly-funded reformatory. Stirling, for example, wasn't interested (SCA, SB1/1/10, Burgh of Stirling Council Minutes, 1901-2: 217, Provost's Committee, 2 August 1902). Indeed, from 123 letters sent Dundee received only 35 replies, epitomising widespread indifference and even antipathy (DCA, Town Council Minutes, 1901-2: 785, 28 May 1902). Dundee ultimately directed its energy into pursuing the Act's amendment rather than implementation.

Councils looked to the lessons of the most ambitious Scottish 'experiment', being undertaken by Glasgow. It spent $£ 9,500^{i}$ purchasing and refurbishing a manor house approximately 20 miles outside of the city in the rural parish of Stewarton in Ayrshire. 'Girgenti' was licensed on 18 December 1900, with anticipated space for 58 and a moralcentred treatment model of farm, dairy and domestic work. Instructively it took over four months to get to just 12 inmates. The Scottish Office had wanted it filled quickly, to encourage the council to build a still larger facility. Glasgow's Sheriff Fyfe claimed cases slipped through his net because of the decision-making of the lower police court. 'It is riotous conduct as a rule which brings people into the hands of the Police,' he explained, 'and by the time a woman so acts as to bring her into the hands of the Police she is generally much worse that (sic.) a drunkard, and so in the opinion of the Magistrates is not a suitable 
subject to send to Girgenti'. This did not wash with the Scottish Office. 'What nonsense this is', reads one acerbic annotation, possibly by Scott-Moncrieff: 'As if the police could not lay their hands on scores of women with 3 convictions'. They could, of course, but this was irrelevant without judicial pathways to prosecution and practical ones to a reformatory (NRS, $\mathrm{HH} / 57 / 63,1627 / 166$, file dated 12 June 1901). This uneven patterning of legal process and outcome exposes just how Edwardian liberty, and the liberalism in which it was rooted, was shaped by the borders and horizons of courts and municipalities. Individuals could exploit this rather limited legislative geographical imagination, for the law offered no power of custody while cases were prepared. Some reportedly left Glasgow before they came to court, for example, while there was no common recording system to count up qualifying convictions across jurisdictions if they were subsequently arrested elsewhere - at least until the 1908 Summary Jurisdiction Act (8 Edward VII c. 65) corrected the defect (see BPP, 1909 [Cd. 4766] XXVI.573: 18). Girgenti would quickly fail without candidates for admission, whatever the feelings of civil servants.

Initially conceived of as mixed sex, a decision was taken in 1901 to restrict Girgenti's use to women - no men having come before the courts on qualifying charges (NRS, HH57/63, 1627/184, file dated 6 September 1901). According to a Scottish Office memo from December 1901 women's drinking became a 'habit', so that while they accounted for less than half of admitted charges for being drunk and incapable $(5,983$ versus 12,706 for men in 1900) they were three times more likely to have been convicted more than three times (139 versus 41 in the year ending June 1901). Repeat arrests spoke as much of judicial habits as drinking ones. Fyfe apparently deemed it a "serious matter to take bread winner 
away from his family" (NRS, HH57/64, 1627/225, 3 December, memo: 8; see McLaughlin 1991: 299). Thora Hands's (2013) analysis shows that many Girgenti women had already separated from their husbands prior to prosecution, although Fyfe's admission hints at the ways gendered social mores shaped regulatory outcomes. He accused Glasgow's magistrates of filtering out cases where they anticipated a 'large amount of trouble' (BPP, 1909 [Cd. 4767] XXVI.601: 157, question 4187). This makes sense given that Girgenti's managers could exercise a veto over admissions, a point of conflict with the Scottish Office. Girgenti's administrators did not want to admit known thieves or prostitutes, nor anybody with an infectious or contagious disease. They wanted people who, if freed from their drink habit, could 'take their places in society as self-supporting citizens' (BPP, 1904 [Cd. 1983] X.793: 15). Between January 1901 and March 1903 they reportedly rejected 108 of 200 qualifying cases (some individuals qualified more than once) (Anon., The Scotsman, 1903: 8). The remaining 92 resulted in 66 admissions to an institution caught between a practical ability to rid the streets of problem drunkards and an ideal to reform its inmates (BPP, 1904 [Cd. 1983] X.793: 15). It risked becoming a 'glorified combination of prison and poorhouse' (NRS, HH57/64, 1627/225, 3 December 1901, memo: 12).

These tensions were tragically embodied in the very first admission to Girgenti. Prison Commissioner A.B. McHardy was called upon to investigate her death from burns, after her nightdress caught fire while she warmed herself in her room. While McHardy apportioned no blame over the incident, he reported that the woman's back story had not been fully known to the managers of the reformatory. She had been 118 times in prison, and McHardy told the chair of the Glasgow Committee that they ought routinely to ask local 
authorities, the Prison Commissioners and the Inspector of the Poor for more information about potential admissions. They should know more about these women's histories before they made judgements as to the management of their futures. McHardy told the Secretary for Scotland that the authorities were not working for the same ends. The police wanted rid of street pests, just the sort of people who were not welcomed by Dr John Carswell, the medical inspector at Girgenti. Stuck in the middle, Sheriff Fyfe was apparently still grappling with the definition of the habitual inebriate. McHardy's conclusion that such determinations were 'to a large extent medical and at any rate psychological', led directly to the appointment of an advisor, James Dunlop, with medical expertise (NRS, HH/57/63, 1627/153, file dated 1 April 1901). Having considered the uneven application of the law I therefore want to examine how these legal and medical questions coalesced in powerful, personal, case geographies that further tested the sorting of governmental responsibility under it.

\section{CASE GEOGRAPHIES}

131 women, Irish and Scottish, Protestant and Roman Catholic, eventually came to Girgenti (Table 1), well short of Scottish Office expectations. Indeed the gap between the promise and the final product became something of a sore point with Girgenti's managers as they were forced to admit a group that challenged their reformatory ambitions. This may well have reflected the gendered nature of moral regulation but even as - and perhaps precisely because - it became a facility for containing rather than curing problem women 
Girgenti's managers struggled. 75 of the first 130 inmates made some attempt at escape, one on 12 occasions (BPP, 1909 [Cd. 4767] XXVI.601: 14, question 277). Another managed to abscond for six months, even managing to get married (BPP, 1906 [Cd. 3073] XVI.167: vi). 29 women spent time in prison during the course of their reformatory sentence, many for escaping or for absconding while on licence to guardians, usually to charities or neighbouring farms. The loosening of entry criteria pulled Girgenti ever more firmly into contemporary institutional, bureaucratic and carceral circuits. So significant was the effect on Girgenti's ambitions that Dunlop warned that exposing a 'higher grade' woman (number 53) to 'women of a very low type' would be a 'cruel punishment rather than reformatory treatment' (NRS, HH57/64, 1627/256, file dated 7 March 1902). That such a putatively ideal case for reform stood out in this way only goes to show how restricted the Act had become.

Table 1, Girgenti (BPP 1910 [Cd.5364] XXXVI.847, Report of the Inspector for Scotland under the Inebriates Acts for 1909: 19. The data in italics are cumulative counts.)

\begin{tabular}{|c|c|c|c|c|c|c|c|c|c|}
\hline Patients & 1901 & 1902 & 1903 & 1904 & 1905 & 1906 & 1907 & 1908 & 1909 \\
\hline In reformatory & 39 & 40 & 39 & 27 & 41 & 44 & 31 & 19 & 1 \\
\hline In hospital & 1 & 0 & 0 & 0 & 0 & 0 & 1 & 0 & 0 \\
\hline $\begin{array}{l}\text { Escaped and } \\
\text { absent from } \\
\text { reformatory }\end{array}$ & 2 & 0 & 6 & 2 & 2 & 4 & 5 & 3 & 3 \\
\hline $\begin{array}{l}\text { Licensed with } \\
\text { guardians }\end{array}$ & 1 & 10 & 18 & 9 & 3 & 2 & 0 & 0 & 0 \\
\hline
\end{tabular}




\begin{tabular}{|c|c|c|c|c|c|c|c|c|c|}
\hline $\begin{array}{l}\text { Escaped and } \\
\text { absent from } \\
\text { Guardians }\end{array}$ & 0 & 7 & 4 & 5 & 4 & 4 & 4 & 3 & 3 \\
\hline $\begin{array}{l}\text { Discharged, unfit } \\
\text { for reformatory } \\
\text { treatment }\end{array}$ & 1 & 3 & 3 & 3 & 3 & 3 & 5 & 5 & 5 \\
\hline $\begin{array}{l}\text { Transferred to } \\
\text { State Inebriate } \\
\text { Reformatory }\end{array}$ & 1 & 5 & 7 & 11 & 13 & 17 & 20 & 20 & 20 \\
\hline Dead & 1 & 1 & 1 & 2 & 2 & 2 & 2 & 3 & 3 \\
\hline $\begin{array}{l}\text { Discharged on } \\
\text { expiry of sentence }\end{array}$ & 0 & 0 & 0 & 29 & 45 & 54 & 63 & 78 & 96 \\
\hline $\begin{array}{l}\text { Total admitted at } \\
\text { end of each year }\end{array}$ & 46 & 66 & 78 & 88 & 113 & 130 & 131 & 131 & 131 \\
\hline
\end{tabular}

Girgenti's location outside Glasgow slowly prompted a series of geographical problems of jurisdiction, particularly concerning people certified during their reformatory sentences. Dunlop later documented the case of 'a low-grade imbecile' Irish woman - in my reading, admission 18 - who proved to be 'unfit for reformatory discipline'. In time, 'on the ground of lunacy', she was passed to Glasgow Parish. That body refused to certify her and instead sent her to Ireland. According to Dunlop she soon 'drifted back to Scotland again, and was in 
and out of prison', but upon his intervention she was removed by Sheriff's warrant to Ireland as a certified lunatic. The Act could not deal with insanity that manifested itself in the reformatory, nor offer any kind of after-care. Upon her discharge, this 'imbecile woman' had simply been 'put on the street'. Certifying her now worked to de-place her, as if the time in Girgenti had severed her ties to Glasgow (BPP, 1909 [Cd. 4767] XXVI.601: 158, question 4203). However much it may have been clinically motivated, Dunlop's intervention also resolved a specific problem of financial responsibility (see NRS, HH67/65, 1627/303 for a discussion of costs in such cases). Very simple local political geographies shaped treatment.

Social policy was shaped by residency requirements - well-documented in the history of the Poor Law (see Gordon, 2015) - that were affected by Girgenti's very location outside the city. Admission 110 was, on 2 March 1906, found saturated with paraffin, apparently with the intention of setting herself on fire. Three days later she was certified as insane and removed to Glasgow Parish's Gartlock Asylum. Its managers requested financial assistance from the Scottish Office, as they felt she had come to them only upon $\mathrm{Dr}$ Dunlop's intervention. She was not actually from Glasgow but a parish in Dunbartonshire, which denied any financial liability as she was no longer living there. This forced Glasgow Parish to chase the managers of Girgenti for costs (NRS, HH57/67 1627/591, file dated 31 August 1906). Having been returned to Girgenti, in September 1906 the woman apparently tried to mutilate her hand by putting it in a fire. Glasgow Parish refused to help: Girgenti was in Ayrshire, outside Glasgow, and they argued that with the elapse of time she had lost her Glasgow settlement, which freed them from responsibility. Girgenti's rural parish, 
Stewarton, refused to get involved: she had come from Glasgow, after all. This presented the managers with an immediate problem. Having been examined by Dunlop and Girgenti's medical officer Dr Cunningham, she was removed to the Ayrshire District Asylum at Glengall. She would remain there until the penultimate day of her sentence (GCA, TD1576/3, Girgenti Superintendent's Journal, 30 September 1907 and 13 November 1907). At this point she was returned to Girgenti. Such a move was no sign of improving health. It was a bureaucratic calculation, for if she had been discharged directly from the asylum she would have qualified as an Ayr lunatic and become chargeable to Stewarton parish (GCA, TD1576/5, Girgenti Register of Admissions; BPP, 1909 [Cd. 4767] XXVI.601: 158, question 4203). Here was an institutional pass-the-parcel, a devastatingly ordinary rendition that met the needs of local authorities. Not two weeks later she was recorded in Glasgow, having taken to drink (GCA, TD1576/3, 23 November 1907). 


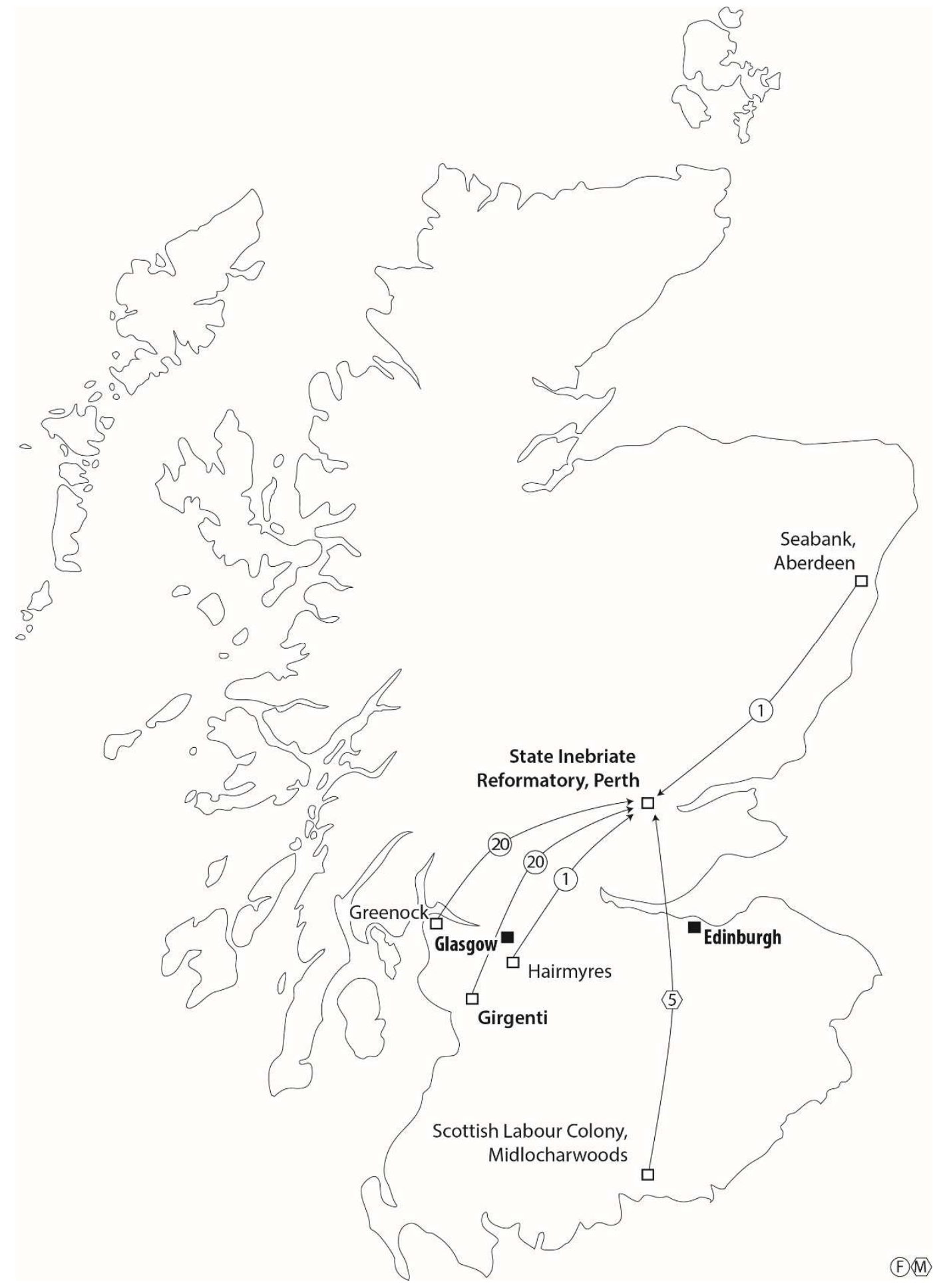

Figure 2, Map showing transfers from local certified reformatories to the State Inebriate

Reformatory, Perth 1901-1914. Shetland (no cases) omitted. (BPP, Reports of the Inspector for Scotland under the Inebriates Acts). 
The emergence of problems within reformatory populations significantly affected the system. The response in 20 Girgenti cases was to transfer individuals to Perth, a 'cumbersome' bureaucratic process that involved 'an application to the Sheriff and attendance before him at Kilmarnock, and also the taking of the inmate to Kilmarnock' (GCA, TD1576/1/1, Girgenti Third Annual Report, 1903: 10) (see Figure 2). Importantly the Corporation's visiting committee admitted that this ability to transfer inmates had induced them to admit women they might otherwise have rejected. They always stated they wanted 'hopeful subjects for treatment', and squarely blamed the Act for restricting them to women 'degraded in the social scale, many being prostitutes, and the larger number paupers' (GCA, TD1576/1/2, Visiting Committee First Annual Report, 1901: 6). Perth's officials resented receiving such 'unmanageables' because their presence made it more difficult to reform section 23 admissions (NRS, HH12/75/1, Visiting Committee minutes, 6 November 1906). Such transfers sorely tested the Act.

Patrick McLaughlin (1991: 301) has argued that the transfer reveals the 'ability of the state to direct people's lives'. He reviews Girgenti case 14, a woman with an extensive history and geography of institutionalisation. On her admission she was found to have venereal disease and was transferred to Glasgow's lock hospital. After her return, she was convicted of a disturbance and sent to Ayr prison. From there she was transferred to Perth, where she declared she would 'make herself so troublesome that we would be compelled to let her go free' (NRS, HH57/63, 1627/194, letter from Town Clerk Depute, 1 October 1901). Her personal case file (NRS, $\mathrm{HH} 19 / 1$ ) is one of just three retained in the National Records of Scotland. It records her separation from her husband, a miscarriage, syphilis, and her 
mother's asylum treatment and subsequent suicide (see Hands, 2013). But it is in the Perth Governor's journal that we see the daily difficulties she posed from her arrival. She 'rebelled' and 'refused to be photographed', and was reportedly tried windows as if to escape (NRS, HH12/74/1, Perth Governor's Journal, 1 November and 5 December 1901). Her disruptive behaviour - destroying clothes, crockery or furniture - often resulted in being placed in a canvas jacket or padded room. She several times reported being hurt by the warders, something the Governor denied in his journal. Of one incident he wrote, 'I had her stripped and examined but found not a trace of injury' (NRS, HH12/74/1, Perth Governor's Journal, 13 February 1902). Of another, discolouration to her shoulders was explained as the result of struggles to remove her to the padded room, against whose walls she subsequently bumped herself to cause disturbances (ibid, 3 October 1902). For McLaughlin (1991: 301), this case 'seems to be explicable not so much in terms of any sociomedical diagnosis, or even some crude classification, as in relation to the inmate's failure to come to terms with institutional reality, an explicit or tacit refusal to allow herself to be institutionally managed'. Medical opinions influenced such cases, and continued to clash unpredictably with bureaucratic considerations.

By turning to the unfolding case geography, we are forced to unpack any sense of a coherent execution of state power: multiple agencies struggled to diagnose, classify and manage. Mapping the movement of inebriates and experts can help glimpse the unstable nature of medical diagnosis, notably nascent psychiatric assessment. .i Dr Dunlop reported that her behaviour was the result of 'recurrent mania', and 'insanity the cause of her inebriety' - which the Act had not sought to address and was ill-equipped to treat (NRS, 
HH19/1, letter dated 21 May 1902). He recommended to the Prison Commissioners that the case be referred to Perth's Procurator Fiscal under the lunacy laws. Geographically, it is telling that Dunlop placed this case within Perth's jurisdiction - i.e. the environs of the prison where she happened to be detained, rather than where she had come from. In June, in matter-of-words that convey a particular power, they discussed her 'disposal', her removal from Perth, asking the Secretary for Scotland for a Sheriff's warrant to transfer her to an asylum to see out her sentence (NRS, HH35/4, Minute Book of Prison Commissioners: 211, 11 June 1902). She was subsequently transferred to a Glasgow parish asylum called Woodilee. Financial questions continued, right down to who should pay to transport her. Glasgow's Town Clerk had wanted her sent to a Perth asylum, complaining to the Prison Commissioners that Glasgow Parish had to deal with people who had been declared insane while in its local gaol, even if their criminal offences had been committed outside its boundaries (NRS, HH67/65, 1627/330, file dated 20 December 1902). Why was this inebriate any different?

Central to my claim for a case geography is to ask what challenges emerged with movement, and not simply what might have necessitated it. The case file may have recorded vital parts of a very moving history, but it was also a space that shaped this individual's future. Dr Marr at Woodilee asylum recorded that apart from 'a slight blunting of the finer intellectual and moral faculties the patient shows in the asylum no signs of insanity' (NRS, HH19/1, Memo from Dunlop to Prison Commissioners, 22 July 1904). This led to her being returned to Perth on the 23 June 1903, much to Dunlop's frustration. After an almost immediate 'maniacal bout' there, lasting two days, Dr Fraser, a Lunacy 
Commissioner, found her to be of 'unsound mind'. She was again sent to Woodilee, from where Marr discharged her at the end of her inebriate sentence on 16 July 1904 into the care of her brother. The Lunacy Board had telegraphed Woodilee to say that if she was not fully recovered then her case must be passed to the local Inspector of the Poor - which would make the parish financially liable for her ongoing care. This did not happen, and they confirmed that she was not bound by their jurisdiction. In this case while the woman was freed from the Inebriates Act she was not freed from drink, and similar rounds of imprisonment and certification followed. Although there is not space to elaborate on the interaction of bureaucratic and medical circuitry, we must note the unstable medical consensus surrounding her mental health. She was, ultimately, admitted to Woodilee chargeable to the parish, and died there in December 1906 (NRS, HH19/1, file 697).

There was no organised system for treating such individuals who had in some senses been brought into view by the Inebriates Act and, who in turn, tested the Act. Moving them only complicated the geography of local jurisdiction, and invited the involvement of the likes of Dunlop in shaping a future that had emerged because of the Act. The two other extant Perth case files, which Thora Hands (2013) analyses in detail, record women transferred from Greenock. They offer tantalising glimpses into attempts by women to shape their own treatment. One, a spinner with 40 convictions at Dundee, had initially been sent to Greenock, but seemingly repeatedly petitioned to be transferred to Perth (NRS, HH19/2). Another complained in two suppressed letters at the length and nature of her sentence. She told her mother, 'my one prayer is to have my health and I will put up with the rest for it is an awful place to have anything wrong with you' (NRS, HH19/3). And to her sister she 
complained of her treatment by Dunlop, who Hands (2013) notes had refused her request for early release. It is unwise to ascribe too definitive a politics to diagnoses and responses to disruptive behaviour. Yet, as Hands (2013) argues, such letters reveal how apparently unmanageable women assessed their treatment and made claims about their transfer and even release. And by placing these in a broader geography of displacement, we can more accurately understand institutional failures to stabilise individual agency, to adapt the argument of Patrick Joyce (2013: 162). We can put the individual at the centre of the strains that ultimately broke the Inebriates Act.

\section{$4 \quad$ FAILURE}

Questions of governmental responsibility exposed a fundamental question of what and whom the reformatory was to treat. Local authorities had plenty of evidence to caution them against burdening their own ratepayers. Those that retained an interest put their energy into agitating for legislative reform based on clearer separations of responsibility. In October 1905, for example, Aberdeen hosted a meeting to consider a reformatory north of the River Tay, which concluded that responsibility for establishing such facilities lay with central government. In a critique of the jurisdictional framing of the Act, it agreed that magistrates should have powers to commit inebriates to institutions (PKCA, PE1/1/29, Town Council Minutes, 1905: 737, 19 October 1905). A further meeting in Dundee the following February resulted in a similar demand and a shared commitment to new legislation (ACAA, 
Town Council minutes, 1905-1906: 120, 19 March 1906; ECA, SL1/1/355, Town Council Minutes, 1905-06: 407, 23 May 1906).

The Town Clerks of Glasgow and Dundee and the County Clerk of Lanarkshire worked together on draft legislation, colloquially known as the Glasgow Bill. While it met resistance, politically its proponents could capitalise on the refusal to respond to their demands. Glasgow threatened to accept no new patients at Girgenti unless the law was changed. This was tested when central government announced it would cut its weekly support from $10 \mathrm{~s}$ $6 d$ to $7 s$ per inmate, after an English philanthropic reformatory provider showed it could operate with lower fee income (BPP, 1909 [Cd. 4767] XXVI.601: 16, question 310). The Scottish Office fought the Treasury to grandfather existing fees, hoping to appease a restless Glasgow (NRS, HH57/68/1, 1627/641, file dated 20 August 1907). The issue of fees flared again when two Glaswegians were admitted at the Scottish Labour Colony Association's certified reformatory at Midlocharwoods in Dumfriesshire - the only such in Scotland to treat men (see Field, 2013: 37). The philanthropic body admitted the men for farm work and industrial training without approval from the council, which then refused to meet its fee obligations. This had the effect of stopping the release of Treasury support. Dunlop used the case to revisit the 'unsatisfactory nature' of the Act: 'The provision of the reformatory is at the good-will of a charitable association, the onus of bringing the cases is at the good-will of a procurator fiscal, and the earning of the treasury grant is at the good will of a local authority. With such complications it is hopeless to expect good working'. While Glasgow gave way, the case highlighted the serious problems of a patchwork system with multiple 
providers (NRS, HH57/70, 1627, D/15, file dated 9 August 1907). It also highlighted how Glasgow needed careful management.

Civil servants hoped that the establishment of a Royal Commission on the Care and Control of the Feeble-Minded would keep Girgenti going, particularly once Dunlop was added to the panel (Jackson, 2000: 206). That inebriety and mental defectiveness were being considered together partly reflected the lessons of the Inebriates Act (Hansard, HC Deb 5 December 1906, vol 166, col 928). The existence of the Commission enabled central authorities to stall on new legislation, testing the patience of local authorities. Remarkably, Home Secretary Herbert Gladstone then appointed a wholly separate committee to review the Inebriates Act - without Scottish representation 'nor interest' in Scotland, to quote Dunlop. One Scottish Office comment predicted Glasgow's reaction: the Act would likely be dead before it had the chance to be revived (NRS, HH57/68/1, 1627/667, file dated 15 July 1908, letter dated 4 May 1908). And when the Royal Commission finally reported, the Town Clerk of Glasgow quickly dismissed its conclusions as not going far enough. By this point the Scottish Office had acted on advice from the Home Office to establish a separate committee of inquiry (NRS, HH57/68/1, 1627/667, ibid, letter from Home Office dated 25 May 1908). This gave Scottish experts their platform, but the proliferation of inquiries only made it harder to produce the consensus necessary for decisive legislative change.

Frictions over reforms exposed the unsatisfactory sorting of governmental responsibilities. Disagreements continued over the role and jurisdiction of police and Sheriff 
Courts, for example. Asked to review Perth's position, the city's Town Clerk reported to its Provost and magistrates that they should follow the Dundee meeting's guidance on powers for magistrates to commit individuals (PKCA, PE28, Magistrates Committee, Bundle 6, Town Clerk report dated 10 November 1908). Dunlop was not convinced: given that English magistrates had jurisdiction over offences involving longer sentences than their Scottish counterparts he felt Sheriffs had to be the relevant authority north of the border (BPP, 1909 [Cd. 4767] XXVI.601: 157, question 4190). The Scottish inebriate inquiry agreed (BPP, 1909 [Cd. 4766] XXVI.573: 17). There was also a question of whether local authorities or central government should be responsible for building accommodation for inebriates. 'The habitual drunkard is nearly connected with the lunatic, and nearly connected with the criminal', Dunlop told the Scottish inquiry, before addressing the divisions of responsibility: 'Lunatics are looked after by parish councils, and criminals are looked after by the state, but town and county councils look after neither' (BPP, 1909 [Cd. 4767] XXVI.601: 156, question 4167). Why would they take on inebriate care, particularly given that the reported reform rate of just 7-8\% hardly represented value for money (BPP, 1909 [Cd. 4766] XXVI.573: 15)? The Scottish inquiry concluded that to get the Act into widespread use it would be necessary to 'transfer the burden to the State' - the cost to be met by a fall in spending on prison places for the same groups prison (BPP, 1909 [Cd. 4766] XXVI.573: 19).

The relationship between alcoholism and mental state, which to repeat was being exposed by these reformatory transfers, was tackled by the Royal Commission on Feeblemindedness. Its work helped to redefine government priorities. Dunlop would tell it that the 'association of habitual inebriety with mental deficiency may be accepted as an 
established fact', and called for statutory provisions for habitual inebriates that were 'similar to that of other classes of mentally defective persons' (BPP, 1908 [Cd. 4202] XXXIX.159: 493). He was arguing for the same authority to be made responsible for the care of habitual inebriates and mentally defective people - namely parish authorities. Anything less, he said, and local authorities would have an 'ever ready excuse' to do nothing and the government would have failed to tackle the 'discrimination' that blighted the Act. It was because of such discrimination that the Scottish inquiry recommended a role for the state that Dunlop appeared to contradict before the Royal Commission. While the former was interested in widening the Inebriates Act, Dunlop's prescription before the Royal Commission was aimed at the particular problem group that had been made visible by it.

Proof of the danger of multiple conflicting reports came when the Scottish Office received a draft Inebriates Bill in March 1912 framed on the findings of the English Departmental Committee. They were frustrated that Scottish demands had been ignored wherever they differed from English consensus (NRS, HH57/68/2, 1627/720, 25 March 1912). Dunlop was reportedly 'dead against' the bill being applied to Scotland. Adamant that they should not repeat the failings of the 1898 Act, he called for separate legislation to tackle local authorities' intransigence (NRS, HH57/68/2, 1627/721, file dated 4 April 1912). But there had been too much conflicting evidence, too many difficult cases to manage, to deliver legislation that would deal with the kinds of inebriates that Glasgow had wanted to treat. The landmark Mental Deficiency Act of 1913 instead focused attention on the group brought into view through the Inebriates Act. It granted powers to re-institutionalise those 
habitual drunkards (as defined by the $1898 \mathrm{Act}$ ) who were also certifiably "defective" (Valverde 1998: 87).iii

This would not be Girgenti's work: it became a farm colony, preparing boys for emigration to Canada (Anon. The Scotsman, 1911: 6). For other inebriate reformatories the end could not come quickly enough, and varieties of transfer a method to exploit. Lanarkshire County Council's reformatory, Hairmyres, had always struggled to fill its 10 beds. When the final two inmates were transferred to prison for absconding, the Council tried to force the reformatory's closure by refusing to readmit them. Dunlop complained that the managers had 'taken the law into their own hands' to escape from their responsibilities (NRS, HH57/71, 1627 C/40, file dated 1 June 1910). Their purpose built facility was 'useless', concluded Dunlop, because local authorities refused to select people 'who would have benefited by treatment there' (NRS, HH57/71, 1627C/46, file dated 23 May 1911, Dunlop's annotation is dated 7 June 1911). When Midlocharwoods' managers naively sought to transfer their few remaining inebriates to Perth, civil servants reacted with anger: 'the Labour Colony authorities have treated this Office as if it didn't exist, \& they should be made to feel their mistake, if possible'. Given that the men's accommodation at Perth had closed and Midlocharwoods was a voluntary institution, discharge was the only available course of action (NRS, HH57/70, 1627 D/40, file dated 20 May 1916, minute dated 24 May 1916). 
Greenock survived the longest because it had never made grand plans to treat inebriety. It had served a simpler function, segregating Greenock's 'street pests' behind its walls, and had used the Inebriates Act to facilitate its existing work. While aware that it might have encouraged some women to transfer themselves to other towns - raising a question as to the scale at which local innovations were introduced and might now be read - police chief Captain Angus lauded its local impact: averaging the nine years before and after the use of the Act in the town, Angus found an annual reduction of 326 offences by women (IA, LG1/1/06 Burgh and Council Records, Magistrates Minutes, 1912-1918, 17 February 1913). But the reformatory was struggling, suffering financially from reductions in government support and increased competition for laundry contracts: its Honorary Secretary James Nicoll told the Scottish Office that they were forced to undercut competitors' tenders, so vital was it to keep the women in work (NRS, HH57/68/1, 1627/691, file dated 14 July 1909). The managers even asked Dunlop to issue a nationwide circular advertising space. Though it had earlier helped advertise Hairmyres, the Scottish Office now rejected this request as 'bolster[ing] up a system, which apparently is a failure' (NRS, HH57/69 1627B/109, dated 12 May 1919). The writing was on the wall.

\section{$5 \quad$ CONCLUSIONS}

I have sought to make a case for bureaucracy as a political space, across which attempts were made to settle governmental responsibilities between the multiple intersecting scales and agencies of the state: to put power in its place (Daley et al., 2017). 
John Carswell, convenor of Glasgow Corporation's Inebriates Committee, complained from the off that they were not able to deal with the non-criminal inebriate (Carswell, 1901: 659). They had wanted to establish a reformatory facility. But as the law reserved inebriety for criminal justice they instead received 'only the flotsam and jetsam of our towns'. As we have seen, Section 24 worked to target a particular group of problem public women, many of whom who were ultimately judged unfit for reformatory treatment (GCA, TD1576/1/2, Girgenti Second Annual Report, 1902: 9). In short, the Act produced a population that its own developing systems struggled to treat.

By reading archive documents as spaces of action and not simply record I have opened up the reformatory and shown how forms of mobility shaped individual experiences and the very future of the system. The movement of people, from police cell to courtroom, reformatory and often on again, unsettled the geographical horizons, the 'horizontal' and 'vertical' jurisdictions, of governmental authority (Beckingham, 2017: 28). Importantly, these 'iterational practices' (Mountz, 2010: 58) provoked a series of bureaucratic as much as medical battles. They became the Act's un-working. To show how, I have linked surviving records together to recover the influence of the inebriate, whose body became a very moving archive with a powerful unfolding case geography. By tracing the emerging frictions involved in their management, I have demonstrated how geographical work can highlight the impacts of those caught in such circuits. Individuals' behaviour was subject to medical observation, and social and legal judgments also repeatedly written on to and read from their bodies. It isn't necessary to adjudicate on the causes of these behaviours in order to see how such people shaped and did not simply suffer policy decisions. For cumulatively 
they tested the very viability of the inebriate reformatory, their cases straining the settlement of local and national government. They exposed, however briefly, the limits of the liberal state. 


\section{Acknowledgements:}

I would like to thank Sidney Sussex College, Cambridge, for its financial support of this work, the staff of the archives I visited for their practical help, and Philip Stickler for providing the outline map for my figures. I presented my developing ideas in Cambridge in 2011, at the RGS-IBG in 2012, in Nottingham in 2017, and at the ICHG in Warsaw in 2018. For their critical input at various stages I am grateful to Jake Hodder, Philip Howell, Alex Jeffrey, Stephen Legg, Francesca Moore and David Nally, the Journal's anonymous reviewers, and Editor Eugene McCann.

\section{Archives}

ACAA Aberdeen City and Aberdeenshire Archives

DCA Dundee City Council Archive

ECA Edinburgh City Archive

GCA Glasgow City Archive

IA Inverclyde Archives, Greenock

NRS National Records Scotland, Edinburgh

PKA Perth and Kinross Archive

SRO Stirling Record Office 


\section{British Parliamentary Papers (BPP)}

1904 [Cd. 1983] X.793, Report of the Inspector for Scotland under the Inebriates Acts (for 1903)

1906 [Cd. 3073] XVI.167, Report of the Inspector for Scotland under the Inebriates Acts (for 1905)

1908 [Cd. 4202] XXXIX.159, Report of the Royal Commission on the Care and Control of the Feeble-Minded

1909 [Cd. 4766] XXVI.573, Departmental Committee on the Operation in Scotland of the Law Relating to Inebriates and Their Detention in Reformatories and Retreats

1909 [Cd. 4767] XXVI.601, Departmental Committee on the Operation in Scotland of the Law Relating to Inebriates and Their Detention in Reformatories and Retreats

1909 [Cd.4682] XXVI.541, Report of the Inspector for Scotland under the Inebriates Acts (for 1908)

1910 [Cd.5364] XXXVI.847, Report of the Inspector for Scotland under the Inebriates Acts (for 1909)

1914 [Cd. 7403) XLV.783, Annual Report of the Prison Commissioners for Scotland (for 1913)

1914 [Cd. 7440] XXXVI.297, Report of the Inspector for Scotland under the Inebriates Acts (for 1913) 


\section{Hansard}

Hansard, HC Deb 5 December 1906, vol 166, col 928

\section{References}

Anon. (1911) New Venture of Scottish Labour Colony Association. The Scotsman, 11 April.

Anon. (1903) The Working of the Inebriates Act. The Scotsman, 3 September.

Beckingham D (2017) "The vice of distant knowledge": Licensing and the geography of jurisdiction on the Scottish wartime Home Front. Geoforum 87: 28-37.

Beckingham D (2010) An historical geography of liberty: Lancashire and the Inebriates Acts. Journal of Historical Geography 36: 388-401.

Blomley N (2014) Disentangling law: The practice of bracketing. Annual Review of Law and Social Science 10(2): 1-16.

Carswell J (1901) The working of the Inebriates Act. The Journal of Mental Science 47(199): 658-666.

Daley P, McCann E, Mountz A and Painter J (2017) Re-imagining Politics \& Space: Why here, why now? Environment and Planning C: Politics and Space 35(1): 3-5. 
Disney T (2017) The orphanage as an institution of coercive mobility. Environment and Planning A 49(8): 1905-1921.

Dittmer J (2016) Theorizing a more-than-human diplomacy: Assembling the British Foreign Office, 1839-1874. The Hague Journal of Diplomacy 11(1): 78-104.

Driver F (1993) Power and Pauperism: The workhouse system 1834-1884. Cambridge: Cambridge University Press.

Field J (2013) Working Men's Bodies: Work camps in Britain, 1880-1940. Manchester: Manchester University Press.

Gill N, Conlon D, Moran D and Burridge A (2018) Carceral circuitry: New directions in carceral geography. Progress in Human Geography 42(2): 183-204.

Gordon WM (2015) The obligation to support the widow: Settlement, the New Poor Law and the Scottish local state. Journal of Scottish Historical Studies 35(1): 45-69.

Gupta, A (2012) Red Tape: Bureaucracy, structural violence, and poverty in India. Durham and London: Duke University Press.

Hands T (2013) Sobering up the Magdalenes' drunken sisters: The institutional treatment of "Female Drunken Pests" in Scotland, 1900-15. Social History of Alcohol and Drugs 27(1): 6281.

Hunt G, Mellor J and Turner J (1989) Wretched, hatless and miserably clad: women and the inebriate reformatories from 1900-1913. The British Journal of Sociology 40(2): 244-270. 
Jackson M (2000) The Borderland of Imbecility: Medicine, society and the fabrication of the feeble mind in late Victorian and Edwardian England. Manchester: Manchester University Press.

Joyce P (2013) The State of Freedom: A social history of the British state since 1800.

Cambridge: Cambridge University Press.

Kotef H (2015) Movement and the Ordering of Freedom: On liberal governances of mobility. Durham and London: Duke University Press.

Li TM (2007) Governmentality. Anthropologica 49(2): 275-281.

McLaughlin PM (1991) Inebriate reformatories in Scotland. In: Barrows S and Room R (eds), Drinking: Behaviour and belief in modern history. Berkeley, CA: University of California Press, pp.287-314.

Milne D (1957) The Scottish Office: And other Scottish government departments. London: George Allen \& Unwin Ltd.

Mitchell T (2006) Society, economy, and the state effect. In: Sharma A and Gupta A (eds), The Anthropology of the State: A reader. Oxford: Blackwell Publishing, pp.169-186.

Moore FPL (2010) Tales from the archive: Ethical and methodological issues in historical geography research. Area 42(3): 262-270.

Moore FPL (2018) Historical geography, feminist research and the gender politics of the present. Geography Compass e12398: 1-8. 
Moran D, Piacentini L and Pallot J (2012) Disciplined mobility and carceral geography:

Prisoner transport in Russia. Transactions of the Institute of British Geographers 37(3): 446460.

Morrison B (2008) Controlling the 'hopeless': Re-visioning the history of female inebriate institutions c.1870-1920. In: Johnston $\mathrm{H}$ (ed), Punishment and control in historical perspective. Houndmills, Basingstoke: Palgrave Macmillan, pp.135-157.

Mountz A (2010) Seeking Asylum: Human smuggling and bureaucracy at the border. Minnesota: Minnesota University Press.

Painter J (2006) Prosaic geographies of stateness. Political Geography 25(7): 752-774.

Parr H, Philo C and Burns N (2003) "That awful place was home": Reflections on the contested meanings of Craig Dunain Asylum. Scottish Geographical Journal 119(4): 341-360.

Peters K and Turner J (2017) Carceral mobilities: A manifesto for mobilities, and agenda for carceral studies. In: Turner J and Peters K (eds), Carceral Mobilities: Interrogating Movement in incarceration. Abingdon: Routledge, pp.1-13.

Philo C (2014) "One Must Eliminate the Effects of ... Diffuse Circulation [and] their Unstable and Dangerous Coagulation": Foucault and Beyond the Stopping of Mobilities. Mobilities 9(4): 493-511.

Salter MB (2013) To make move and let stop: Mobility and the assemblage of circulation. Mobilities 8(1): 7-19. 
Smith I (2018) Doctoring in a whisky-injured nation: The medical response to the "alcohol question" in Scotland, 1855-1925. MD Thesis, University of Glasgow, UK.

Soares C (2015) The path to reform? Problematic treatments and patient experience in nineteenth-century female inebriate institutions. Cultural \& Social History 12(3): 411-429.

Sutherland JF (1899) Urgency of legislation for the well-to-do inebriate. British Medical Journal 2(2020): 718-721.

Valverde M (1998) Diseases of the Will: Alcohol and the dilemmas of freedom. Cambridge: Cambridge University Press.

Vissman, C (2008) Files: Law and media technology. Translated by Geoffrey WinthropYoung. Stanford: Stanford University Press.

Wallis J (2018) A Home or a Gaol? Scandal, secrecy, and the St James's Inebriate Home for Women. Social History of Medicine 31(4): 774-795.

Wolch J and Philo C (2000) From distributions of deviance to definitions of difference: Past and future mental health geographies. Health \& Place 6(3): 137-157.

Zedner L (1991) Women, Crime, and Custody in Victorian England. Oxford: Clarendon Press.

\footnotetext{
'According to the UK National Archives' currency converter, the cost is equivalent to an estimated purchasing power in 2017 of $£ 742,635.90$. See http://www.nationalarchives.gov.uk/currency-converter/ (last accessed 22 May 2018).
} 
ii See Philo's (2014: 499) analysis of the 'embodied presence' of medical expertise within asylums; and Smith (2018) for a discussion of local reformatories' reliance on generalists selected for their geographical proximity to institutions.

iii Valverde (1998: 58) argues the London County Council's reformatory morphed into 'an institution for feeble-minded women, apparently with no change in the regime'. 